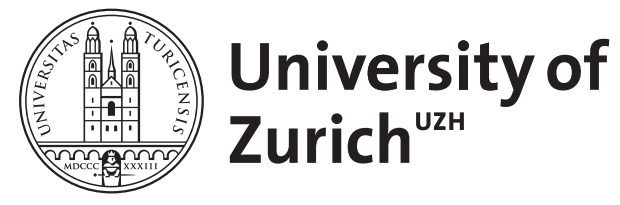
Archive

University of Zurich

University Library

Strickhofstrasse 39

CH-8057 Zurich

www.zora.uzh.ch

Year: 2018

Gottfried Semper's Dresden Synagogue Revised: An Echo of the Alhambra?

von Orelli-Messerli, Barbara

DOI: https://doi.org/10.3726/b10940

Posted at the Zurich Open Repository and Archive, University of Zurich

ZORA URL: https://doi.org/10.5167/uzh-157156

Book Section

Published Version

Originally published at:

von Orelli-Messerli, Barbara (2018). Gottfried Semper's Dresden Synagogue Revised: An Echo of the Alhambra? In: Giese, Francine; Varela Braga, Ariane. The Power of Symbols : The Alhambra in a Global Context. Bern: Peter Lang, 139-152.

DOI: https://doi.org/10.3726/b10940 


\section{THE POWER OF SYMBOLS}



Francine Giese, Ariane Varela Braga (eds.)

\title{
THE POWER OF SYMBOLS
}

\author{
THE ALHAMBRA IN \\ A GLOBAL PERSPECTIVE
}

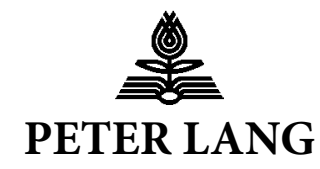

Bern • Berlin • Bruxelles • New York • Oxford • Warszawa • Wien 


\section{Bibliographic information published by die Deutsche Nationalbibliothek}

Die Deutsche Nationalbibliothek lists this publication in the Deutsche Nationalbibliografie; detailed bibliographic data is available on the Internet at 〈http://dnb.d-nb.de〉.

British Library Cataloguing-in-Publication Data: A catalogue record for this book is available from The British Library, Great Britain

Library of Congress Control Number: 2018933130

Cover: Alhambra, Court of Lions, detail of arcade. @ Bildarchiv Foto Marburg / Thomas Scheidt and Christian Stein

ISBN 978-3-0343-2727-5 pb.

DOI 10.3726/b10940

(c) Peter Lang AG, International Academic Publishers, Bern 2018

Wabernstrasse 40, CH-3007 Bern, Switzerland

bern@peterlang.com,www.peterlang.com

All rights reserved.

All parts of this publication are protected by copyright.

Any utilisation outside the strict limits of the copyright law, without the permission of the publisher, is forbidden and liable to prosecution.

This applies in particular to reproductions, translations, microfilming, and storage and processing in electronic retrieval systems. 


\section{Gottfried Semper's Dresden Synagogue Revised: An Echo of the Alhambra?}

Barbara von Orelli-Messerli

Strange enough, Gottfried Semper's Dresden Synagogue never has been published in a proper way. That is to say, the greater part of the architect's drawings for this building are still unpublished. What are the reasons for this curious fact? Lacking interest on the side of the former German Democratic Republic? Lacking interest on the side of the Jewish community in Dresden? Or even lacking interest on the side of the historians of architecture, who of course have published several drawings of Semper's synagogue but never the whole set?

Gottfried Semper's Dresden Synagogue is my current research project, in a way a continuation of my habilitation and publication on the architect's designs for decorative arts $^{1}$. I began with a wider investigation in summer 2016, visiting first the archives of the gta (Institute for the History and Theory of Architecture) at the Swiss Federal Institute of Technology (ETH) in Zurich, followed by a three-week stay in Rome researching at the Bibliotheca Hertziana. And just at the end of August, I went to the Dresden archives and libraries holding documents concerning the Old Synagogue, as it is called now. In this way, my paper is a work in progress. I will at this stage not be able to give exhaustive answers to all the questions, which may be raised by the subject, but I will present a sort of display of the different elements on the way to a larger publication.

Let us consider first the questions arisen by the research project: it was always postulated that Semper's synagogue was built with an exterior architecture in a neoRoman style and that the interior was conceived in the Moorish style, whatever that means. So our first question concerns this division, whether we want to uphold it or whether we want to scrutinize the given order and introduce new elements as far as form and interpretation are concerned. Our second question: if we accept that the interior took over elements of an Islamic ornamentation, we can ask for the models of this decoration. Can we refer to certain drawings, publications or was it the full invention of the Dresden architect? And finally, our last question concerns the affiliation of the Dresden Synagogue. Often cited in the literature as the 'mother of European synagogues' in the nineteenth century, we may ask whether it really was the 
first synagogue in Oriental style and if it was really Gottfried Semper who introduced Islamic architecture in Europe.

Let us begin with the last question, which is insofar of architectural interest as it will show us, that decorating and building in Oriental style was already en vogue in the first quarter of the nineteenth century. It was Eugène Beauharnais, son of Joséphine and stepson of Napoleon I, who conceived a Boudoir turc in the Hôtel Beauharnais in 1803-1805. Oriental style became in the first half of the century one of the favorite interior decorations if exoticism was on demand. If we ask for the first synagogue built in Islamic style, we have to go to the Munich architect Friedrich von Gärtner, the same whose lectures Gottfried Semper attended in the winter term of 1825, having inscribed as a student at the Architectural Department of the Academy of Arts².

It was in Ingenheim where Friedrich von Gärtner conceived, together with August von Voit, the local synagogue (fig. 1). We know that Von Gärtner drew three projects for this building, the last being accepted for execution in 1830 . Whereas the exterior was designed by Von Gärtner in Islamic style, the interior, due to August von Voit, was in a neo-classical style. The consecration of the synagogue took place on December 10,1832. In the prayer hall, on the ground floor, was space for 240 men. 170 women, relegated to the galleries, could attend the service.

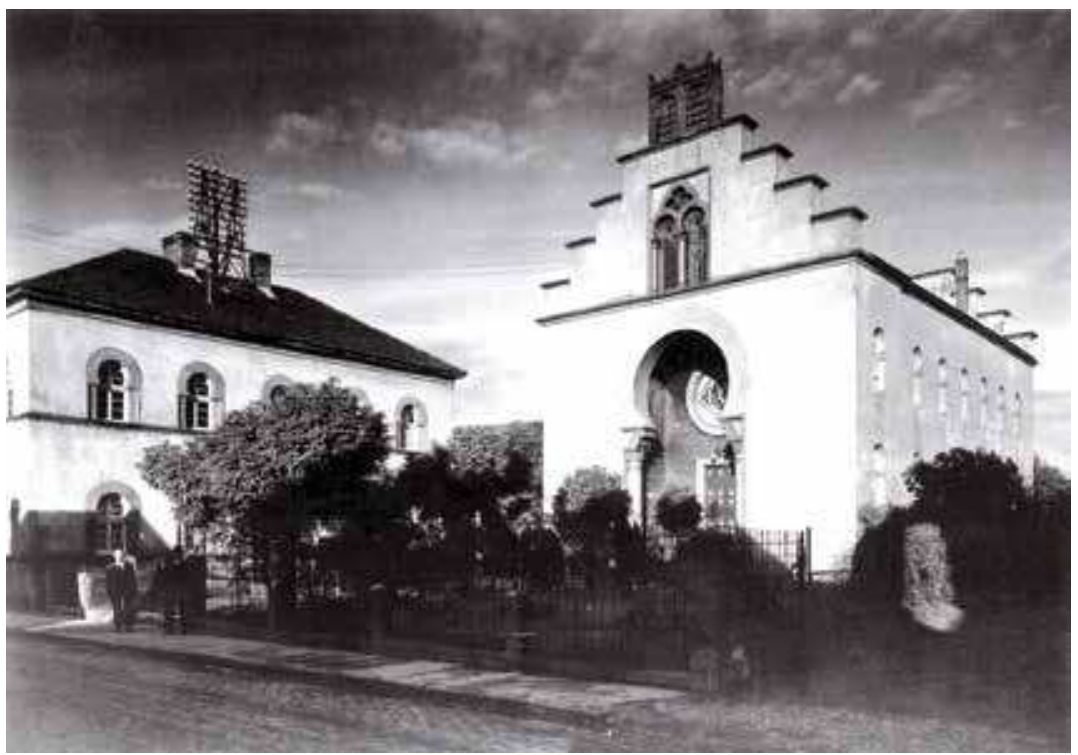

Fig. 1: Ingenheim, Synagogue and the Rabbi's house in Ingenheim, view from the southwest-side, Friedrich von Gärtner, 1830, photographed before 1938. () Anton Eckhardt. 
In this context we may raise the question, if and if yes how far the Baukunstausschuss (or Committee for Architecture) founded in 1829 by Ludwig I of Bavaria had influence on this building. This board of high-class architects, located in Munich, discussed during its meetings the architecture to be built in Bavaria. Members of the board were among others Leo von Klenze, Friedrich von Gärtner, Johann Gottfried Gutensohn or Friedrich Ziebland ${ }^{3}$. The first aim of Ludwig I through his Committee for Architecture was to disseminate exemplary architecture all over Bavaria, be this buildings planned and executed by the Bavarian State, by communities or by foundations. In his decree (Entschliessung) Ludwig I names town halls, prisons, churches, synagogues as well as fountains which plans had to be submitted to the Baukunstausschuss ${ }^{4}$. The Synagogue of Ingenheim by Friedrich von Gärtner shows us, that this project was part of the Bavarian renaissance of architecture under the guidance of Ludwig I. Conceived in Islamic style, it became a standard for synagogues, sort of a mutual agreement within the board of Bavarian architects. Typical element of Islamic-style architecture was the horseshoe-arch, an element, we find in Ingenheim in the entrance as well as in the double-arched window above. The synagogue of Ingenheim was destroyed in the night of November 9 to 10, 1938 (Pogromnacht or Kristallnacht). Practically at the same time as Ingenheim, the community of Feuchtwangen planned its new synagogue, consecrated in 1833 .

The synagogue of Kirchheimbolanden was planned by August von Voit in 1834 and the construction began in the following year (fig. 2). The ground floor was occupied by an apartment for the teacher as well as a classroom, whereas the prayer hall was placed on the first floor. For this synagogue Von Voit adopted Islamic style for the exterior aspect as well as for the interior decoration. The building is characterized as "neoclassical-moorish mixed style" (klassizistisch-maurische[r] Mischstil). Its general form is inspired by neoclassical architecture, but its main facade has an entrance over-arched by a horseshoe-arch and above it the double-arched window crowned by an oculus. On the sides of the building, three rows of windows are displayed, belonging to the ground-floor, the first floor and the second floor, all with horseshoe-arches, again hints to Islamic style. The plans of August von Voit are the only sources for this synagogue. Burned down in the Kristallnacht, its remains were removed in 1941 .

\footnotetext{
See Hopfenmüller 2015, 46.

See Hopfenmüller 2015, 9.

Hopfenmüller 2015, 9.
} 


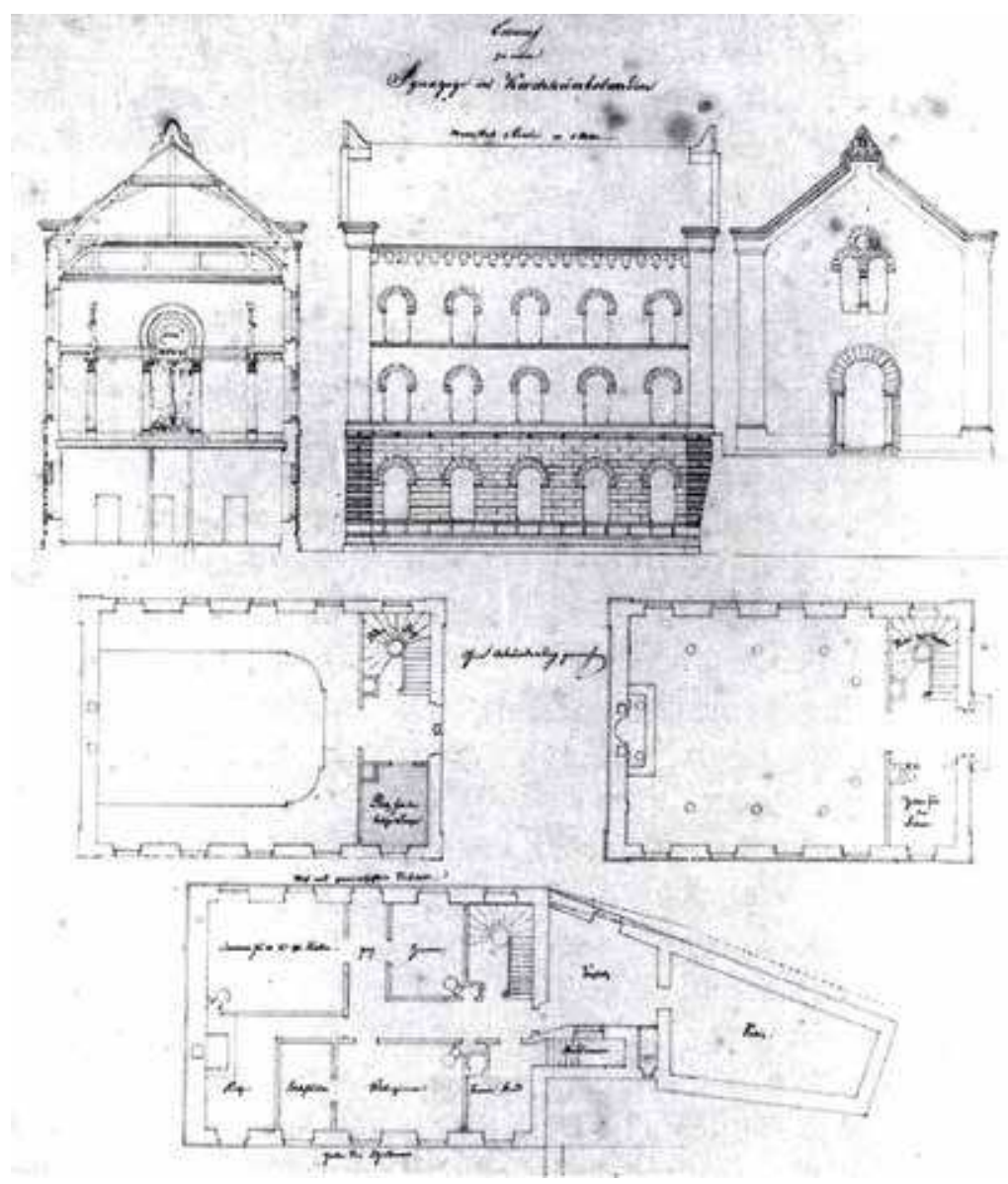

Fig. 2: Kirchheimbolanden, Study for the Synagogue in Kircheimbolanden, August von Voit, 1836. (c) Bayerisches Hauptstaatsarchiv München.

The synagogue of Speyer, planned by August von Voit in 1836 and consecrated on November 24, 1837, is another neoclassical building adorned with elements of Oriental architecture (fig. 3). The entrance is over-arched by a horseshoe-arch as well as the three windows above. The windows on the two sides of the building show again this characteristic Islamic architectural element ${ }^{6}$. The Speyer synagogue was also burned down in the Reichskristallnacht and on the following day the major of Speyer gave his permission to tear down the ruin.

6 See Arbeitsgemeinschaft 2016. 




Fig. 3: Speyer, Synagogue in Speyer, view of the main and side façade, August von Voit, 1836/37, enlarged 1866, photographed in the 1930's. () Stadtarchiv Speyer.

So if we have now to answer our question, whether Islamic style in architecture was already in use in the German speaking part of Europe before Gottfried Semper's Dresden Synagogue, we can definitely answer yes. A strong impetus, as we noted, came from Bavaria and the Baukunstausschuss, founded in 1829 by Ludwig I and we can state that none other than Friedrich von Gärtner himself gave the starting signal for synagogues in Islamic style.

If we now move on to answer our second question, whereas there have existed models for Gottfried Semper's Dresden Synagogue, we have to consider the architecture of the building and then its interior architecture and decoration. Gottfried Semper published his synagogue in the Allgemeine Bauzeitung in 1847, almost ten years after its completion, as the laying of the cornerstone took place on June 21, 1838 and the consecration on May 8, 18407. (fig. 4) The description of the synagogue in the Allgemeine Bauzeitung by Gottfried Semper is a more technical-material one. Concerning its architecture, he gives no hints to its style. The painted decoration on the walls in the prayer hall are described as "mit maurisch-byzantinischen Mustern verziert" 8 that will say decorated with Moorish-Byzantine patterns. His terminology, as it seems to us, has to be translated as a combination of Islamic and Byzantine patterns.

$7 \quad$ See Semper 1847, 127.

8 Semper $1847,127$. 


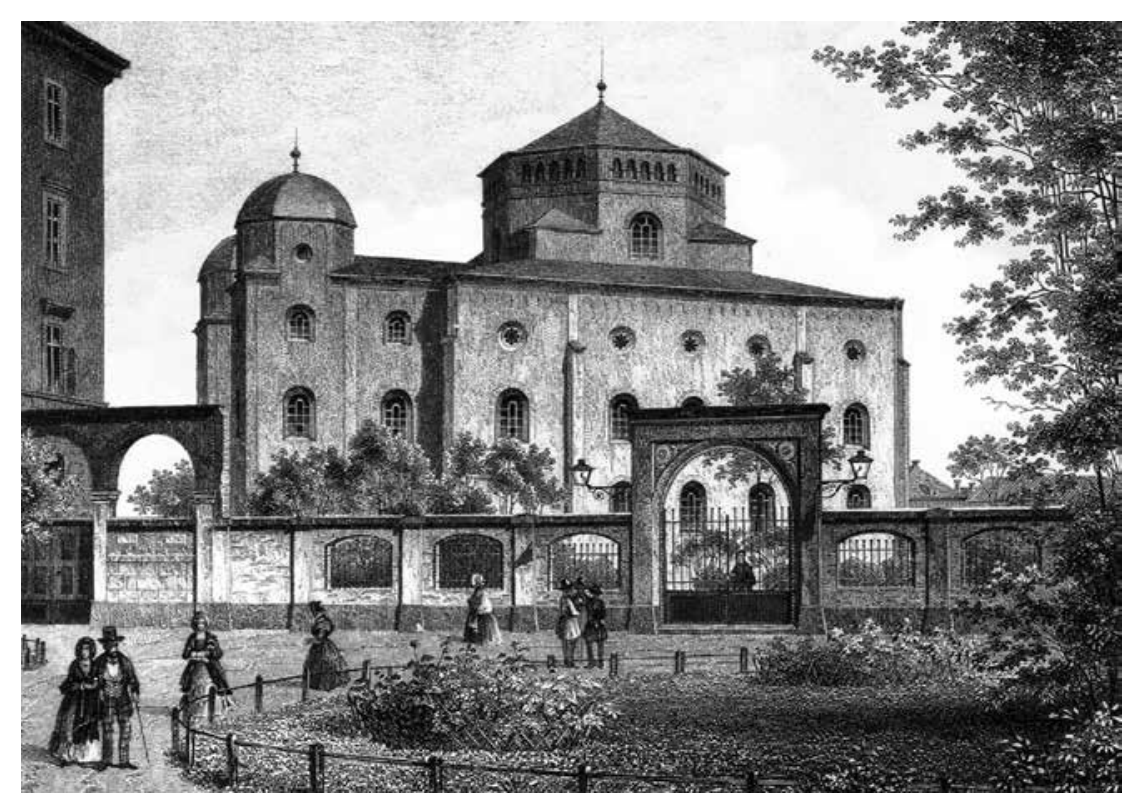

Fig. 4: H. Krone (Photograph); L. Thumling (Lithography), Synagogue in Dresden, c. 1860, Lithography after copper engraving, $145 \times 195$ mm, Dresden, Archiv der Hochschule für Bildende Künste, Dresden, no. inv. 1006. () Archiv Hochschule der Bildenden Künste, Dresden.

If we have to define the architecture of the Dresden Synagogue, we can describe it as built in the so called 'Rundbogen-Stil', a style with simple rounded arches which in some way refers to the Roman style of the 10th and 11th century in Germany as well as a main façade with a pair of towers. We note that Semper made no use of the horseshoearch for his synagogue and the exterior of the building shows no other elements of Islamic style. It presents itself in a historic self-consciousness, integrated in the baroque Dresden townscape in a way pretending having always stood on the left shore of the Elbe. The synagogue, as projected by Semper, is a square building, aligned to the east, with an atrium at the west-side which served as winter-synagogue or assembly hall for the Jewish community. The main entrance was on the south-side of the atrium, due to the fact that the access from the west-side was narrow and not representative. The two towers of the west-side hadn't been conceived to be built high up by Semper, but in some way ducked down, not taking too much importance in the townscape of Dresden but nevertheless counterbalancing the important volume of the prayer hall. The interior of the synagogue, especially the prayer hall, has been described by Hannelore Künzl as giving the impression of a coherent oriental decoration, "even in details not inspired by Islamic style, but showing elements evoking the Orient in general". A glimpse of the prayer hall puts us in presence with elements of the Alhambra, especially the columns with the two-zoned capitals, present in the Nasrid Palace. Going from this point further, 
it is quite easy to establish the connections between Gottfried Semper and the Alhambra, respectively between the first exhaustive publications of this building in Granada, which arose interest in whole Europe (fig. 5).

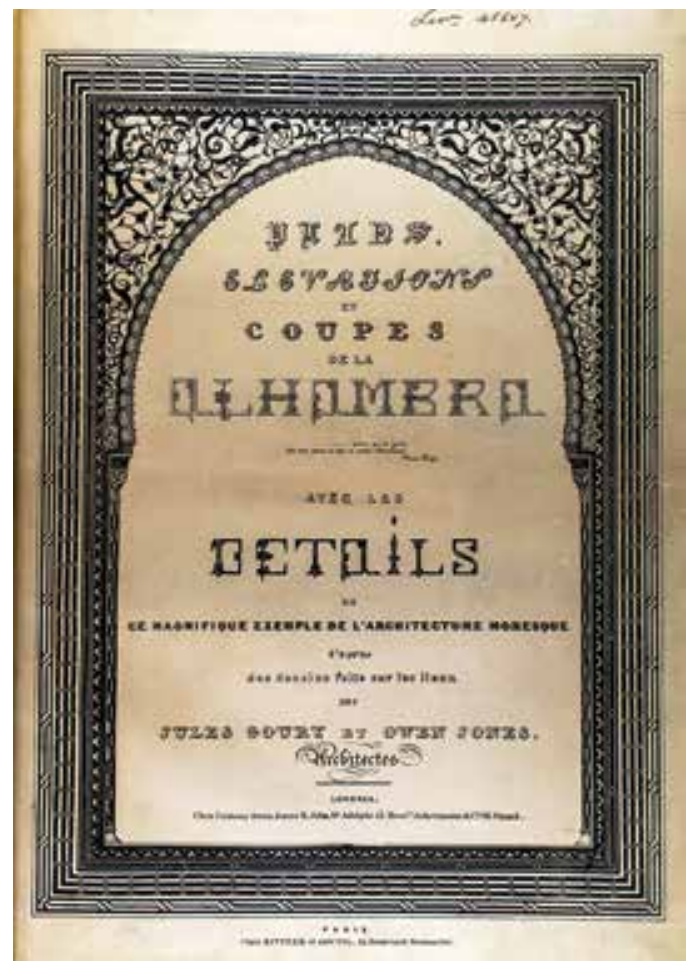

Fig. 5: Jules Goury, Owen Jones, Plans, elevations and sections of the Alhambra with the elaborate details of this beautiful specimen of Moorish architecture / from drawings taken on the spot in the year 1834 by Jules Goury and Owen Jones, 1836/1840, cover page. The exemplar is numbered on the title-page with "No. 88". (อ Archiv der Hochschule der Bildenden Künste, Dresden.

We have to go back to Jules Goury and Owen Jones, the authors of Plans, Elevations and Sections of the Alhambra (1836-1840) ${ }^{10}$. In this context it has to be reminded, that the first edition of this book, or better the publication of the plates began in 1836 , published in compounds of five plates from 1836 on to $1840^{11}$. The first number was printed on April $11^{12}$, and Owen Jones himself put an advertisement in The Literary Gazette; and Journal of Belles Lettres, Arts, Sciences of April 16, 1836: "No. 1. La Alhambra. A Selection of Plans, Elevations, Sections, and Details, of this

10 See Goury/Jones 1836-1840.

11 See Goury/Jones 1836-1840. See title page: "Cet Ouvrage se composera de DIX LIVRAISONS ; chacune d'elle contiendra cinque [sic] planches, dont deux seront des Elevations ou des coupes gravées au trait par les premiers graveurs ; et les trois autres, dessinées sur la pierre [...]."

12 See Darby 1974, 95, ftn. 38. 
Beautiful Specimen of Moorish Architecture, so unexampled for the Purity of its Ornaments and the Richness of its coloring"13. Jones ambitious undertaking had to be financed by subscribers, who would receive "Ten Numbers, each containing Five Plates. Two of which will be Sections and Elevations of the building in neat outline, by the first Engravers, and printed in Colours in exact imitation of the Original Drawings" 14 . Jones points rightly to the fact of the "Richness of its colouring", as he was one of the first using Godefroy Engelmann's method of colour-printing 'chromolithorgraphie', who was delivered a patent for this colour-printing method a little more than a year later in Paris "pour des procédés d'impression lithographique en couleurs"15.

This first edition of Plans, Elevations and Sections of the Alhambra is without any commentaries, even if Jones had had the intention to provide, according to his advertisement in The Literary Gazette: "A descriptive account, with a short Treatise on Arabian Architecture: [which] will be presented to Subscribers, at the completion, or during the progress of the Work" ${ }^{16}$. Only in the second edition Jones provided the promised commentaries ${ }^{17}$. This first edition of Plans, elevations and sections of the Alhambra gives us the possibility to make a close link between Semper's Dresden Synagogue and the Alhambra, as its publication began just two years before the planning of the "Gotteshaus", as Semper called it sometimes.

But how comes that Semper had the sumptuously colored plates as well as the plates printed in black before his eyes? To be exact, Semper never possessed these plates of the Alhambra, but ordered them through the - at this time called Akademie der Künste, where he was a professor for architecture ${ }^{18}$. It was not only his interest in colored architecture which made him order this edition of the Alhambra, but also the fact that he had got acquainted with the two authors. Colored architecture was for Semper a given cultural fact, embracing different times and cultures. So he could write in his first publication of 1834: "All times of high cultural education are conform concerning this principle, a fact which [generally] is denied. The Greeks, the Moors, the Normans, the Byzantines as well as the pre-Goths, yes, even the Gothic masters themselves practiced it" ${ }^{\prime 1}$. Colored architecture was also the reason why Gottfried Semper and Jules Goury travelled to Sicily and Greece in 1831 to do their research work on ancient polychromy.

13 Jones 1836, 253.

14 Jones 1836, 253.

15 Owen Jones, letter to John Murray, December 1839, cited in Darby 1974, 49, ftn. 49.

16 Jones 1836, 253.

17 See Goury/Jones 1842-1845.

18 The so called Duty lists (Zollisten) of Semper's books, which he had to hand over to the British authorities, when they were sent to him to England after his exile in May 1849, show no valuable illustrated books. See gta Archiv, Institut für Geschichte und Theorie der Architektur (gta), ETH Zürich. Nachlass Gottfried Semper, Zolllisten, Inv. Nr. 20-Ms-148.

19 Semper 1834, 20. 
Carol Ann Hrvol Flores writes in her thesis on Owen Jones: "For in choosing to visit Italy, Sicily, and Greece in 1831, he [Jules Goury] selected the three areas most studied in investigations on the decorative use of color in ancient architecture" 20 . Without entering in the quite widespread discussions on polychromy of ancient and more recent architecture and sculpture, we can say that these studies conducted by Semper and Goury were well intended, as it was one of the foremost research topics of this young generation of architects. Semper himself recalls Goury in his publication of 1851 Die vier Elemente der Baukunst: "After we separated in Athens, Goury together with Mr. Owen Jones, the future author (editor) of the well-known magnificent work on the Alhambra, continued his researches in Egypt and Syria where he died of cholera in 1834" ${ }^{21}$. Carol Ann Hrvol Flores gives the exact route of Goury and Jones, based on one of the rare personal documents of the latter: "Italy, Sicily, and Greece in 1831, Egypt and Constantinople in 1832 and 1833, Spain [...] in 1834"22. In this year Jules Goury died in Granada. Owen Jones travelled home, going first to France to inform the family of the death of his friend and then returned to England in 1835.

These explanations show us the special interest Semper had in the publication of the Alhambra and why he did not hesitate to order it for the Library of the Akademie der Künste in Dresden when teaching there as professor and practicing as an architect, planning and executing at the same time the synagogue, the Royal Court theater, and the Villa Rosa, a summer residence on the shores of the Elbe of a rich banquier.

If we have now to answer our second question whether Gottfried Semper had inspirations and ideas from particular publications, we can answer, yes, he had, and in conceiving the Dresden Synagogue, he had before his eyes the plates of the Alhambra, drawn by Jules Goury and Owen Jones, printed and edited by the latter. Let us make a remark on this volume of 1836/1840 - and here we take the first and the last dates on the plates themselves - in the library of the Hochschule für Bildende Künste in Dresden (fig. 6). The plates are - compared with the edition of $1842-$ not in a proper order, show traces of use and dust, are sometimes torn and mended afterwards and have a bookbinding which probably was made in the second half of the nineteenth century, that will say after Semper's exile to Paris, London and Zurich. To show the inspiration Semper took from the Alhambra publication, we choose plate 23 of the Dresden volume and plate 16 of the edition of $1842^{23}$. The

20 Flores 1996, 21.

21 Semper 1851, 3; for the translation see Flores 1996, 17.

22 Flores 1996, 17.

23 At this point, we can correct the opinion of Hannelore Künzl who wrote: "Diese Kapitelle sind auch in der Publikation von Owen Jones abgebildet, doch kann Semper sie nicht von dort her kennen, da die Alhambra-Publikation von Jones 1842 u. 1845 erschien, sondern eher aus früheren Werken, etwa dem von Girault de Prangey."

Künzl 1984, 169-170. Interesting enough, Girauld de Prangey's publication is not in the possession of the library of the Hochschule für Bildende Künste. We did not find it in the already above 
plate rendering the Patio de los Leones gives details of the center-arch, not only of the arch itself, but also the columns and the capitals. Semper has adopted the twozone capital form. The imitation of the lower zone with its long drawn-out leaves is quite evident, whereas the upper zone with vegetal ornamentation shows a free interpretation of the given model. Over the capital we find an ornate abacus and above it a high cubic block connecting the capital with the gallery and supporting it. The front and backside of these cubic blocks have an architectural ornament recalling a sort of entrance with two columns on the right and left longitudinal edge. The arches are going from the upper part of the block to the opposite side and the spandrels, and - as far as I can understand - are in their form not inspired by Alhambra models, but have - let us say - more Chinese than Islamic forms.

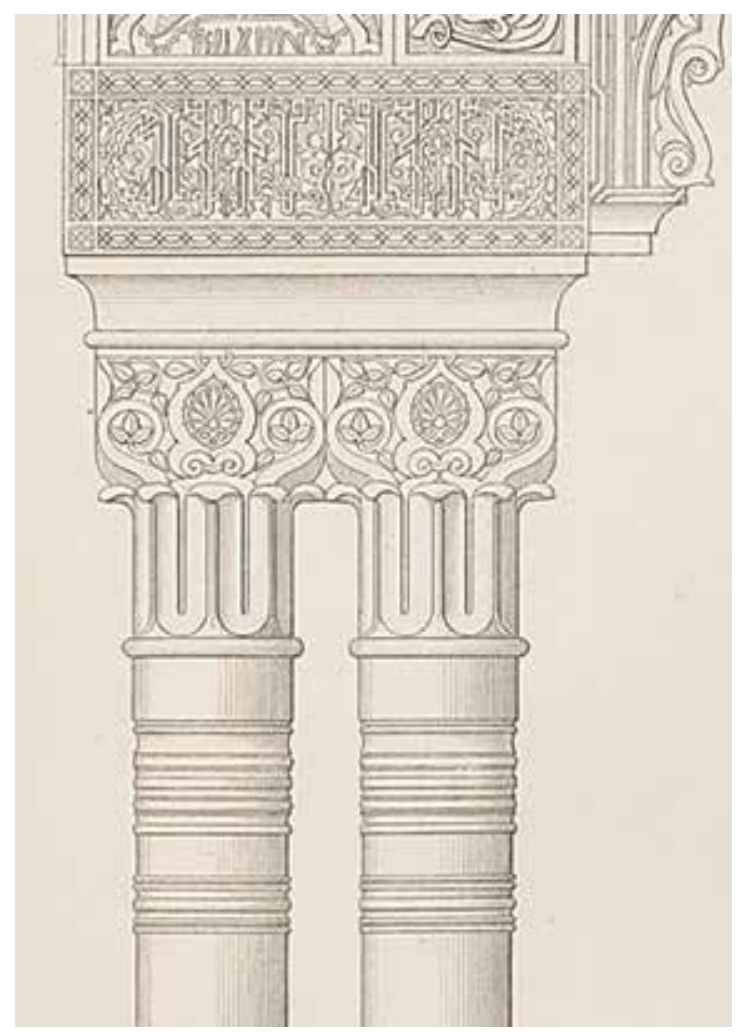

Fig. 6a: Details of the capitals: La Alhambra, Patio de los Leones. Detail of the arch of the Court of the Lions. Scale 1/10. Jules Goury del., E. Kennion sculpt., Published by Owen Jones, London 1836/1840. Plate 23. (๑) Archiv der Hochschule der Bildenden Künste, Dresden.

mentioned Zollisten of Semper in the gta Archiv, Institut für Geschichte und Theorie der Architektur (gta), ETH Zürich. Nachlass Gottfried Semper, Zolllisten, Inv. Nr. 20-Ms-148. See also Girault de Prangey 1837 and Girault de Prangey 1842. 


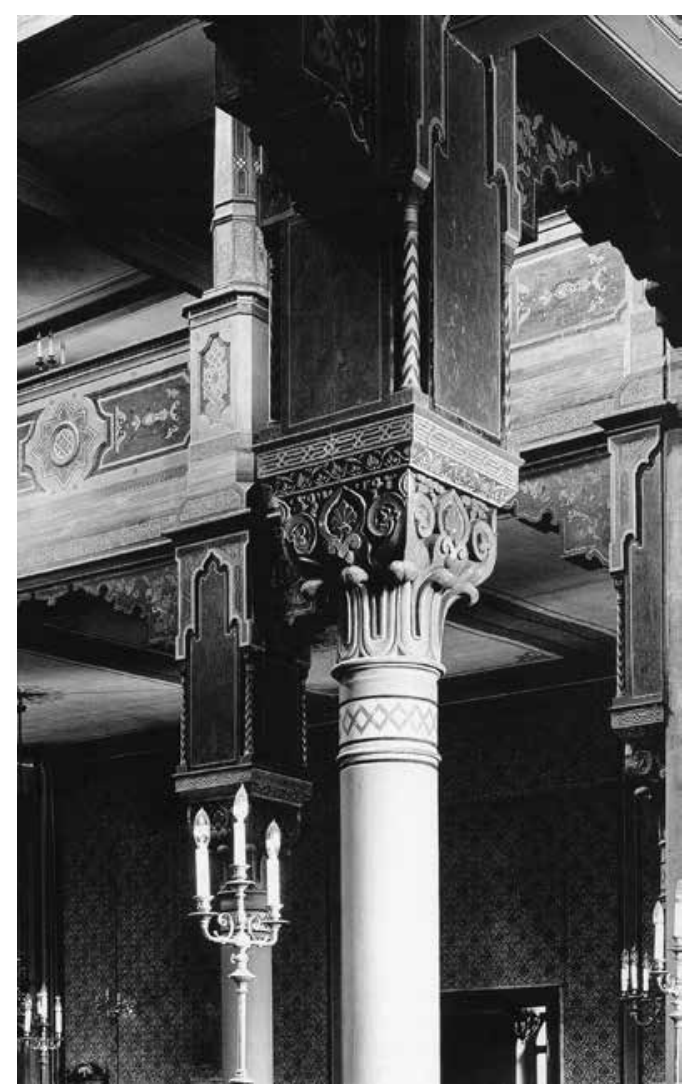

Fig. 6b: Dresden, The Synagogue in Dresden with details of the capitals, photographed 1917. (C) Bildarchiv Foto Marburg, Marburg.

It is not the place here to give you an exhaustive analysis of the ornamentation of the Dresden Synagogue. At this point of my research, concerning this building, I would not consider the interior as "alhambresque" style, to take up an expression coined by Anna $\mathrm{McSweeney}{ }^{24}$. A detailed analyze has to show the different ideas intervening in this building like the vertical ornamental sections with stars of David on the walls of the prayer hall. ${ }^{25}$ But here again, Semper and his architectural universe are immense and multifold and one is well advised to expect more than one explanation. But I would like to show one last detail, the dome in the center of the prayer hall, a detail, which is - as far as I know - not fixed in any photography and even not rendered in the lithography of the interior of the synagogue (fig. 7).

24 McSweeney 2015, 44.

25 See Gottfried Semper, drawing for part of the lateral façade as well for interior decoration (detail), 1838/, pencil on paper, 660 x 550 mm, Archiv der Hochschule für Bildende Künste, Dresden, no. inv. B 772 . 


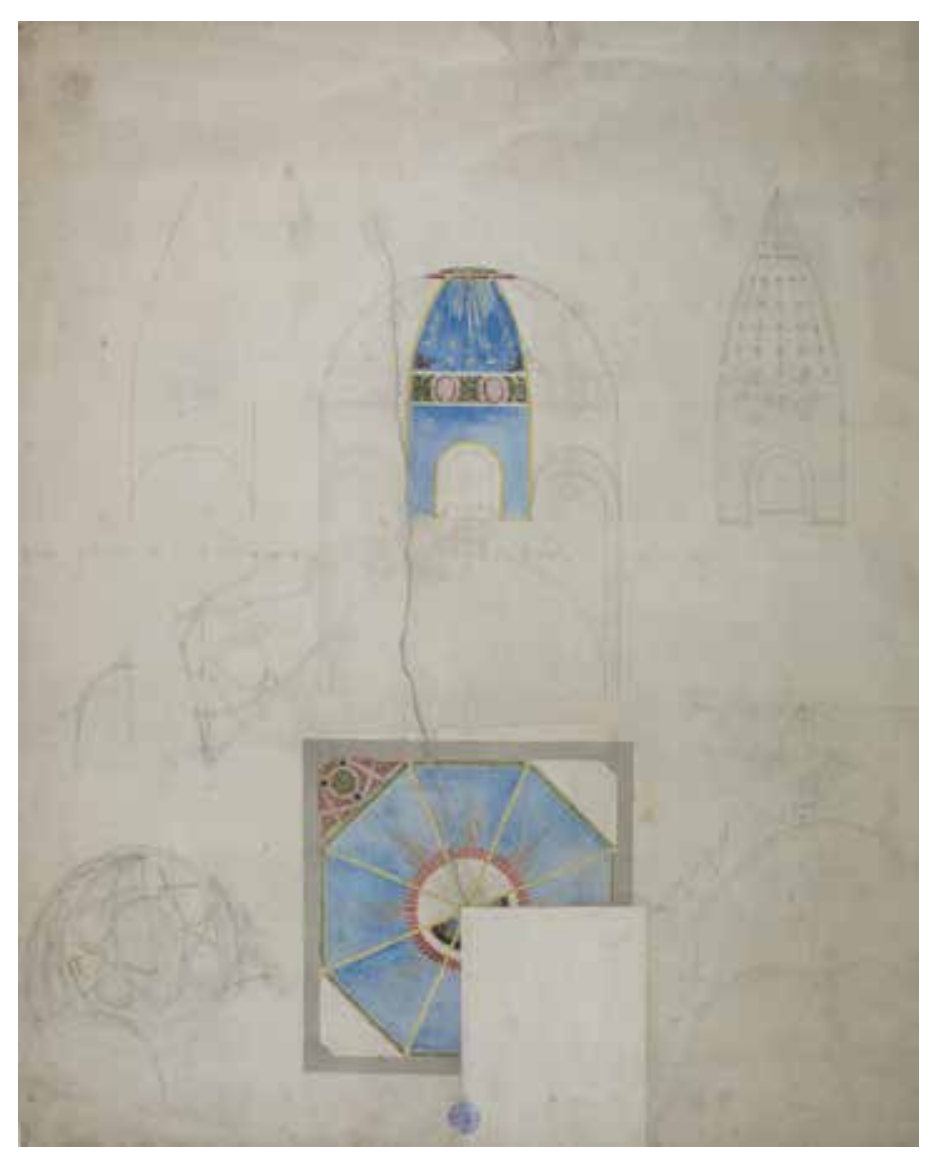

Fig. 7: Gotffried Semper, Synagogue in Dresden. Longitudinal and lateral section view of the dome with details including colour design, 1838/1840, pencil and black ink drawing, colour wash, 620 x 508 mm, Hochschule für Bildende Künste, Dresden, no. inv. B 771. () Archiv der Hochschule der Bildenden Künste, Dresden.

The inner side of the dome was planned and executed by Semper as a starry sky. This shows us that Semper had also other ideas for his Dresden Synagogue than coming from the publication on the Alhambra. In his description of the building in the Allgemeine Bauzeitung he writes: "The coloring of the inner side of the dome is blue and shows in its center a ceiling with the starry sky which has symbolic reference to the Seven Heavens of the Old Testament" ${ }^{26}$. In the drawing of Semper, this sky is not rendered as an astronomical sky, but the stars are distributed on the inner side of the dome quite regularly and therefore it can be seen as an ornament, in the same way as Karl Friedrich Schinkel conceived it for the coulisses of Wolfgang Amadeus

26 Semper 1847, 127; see also 2 Enoch. 
Mozart's The Magic Flute ${ }^{27}$. It is Oleg Grabar who drew our attention to the fact, that the dome in the Hall of the Two Sisters in the Alhambra, with reference to the poem for the Palace of Ibn Zamrak, can be seen as the turning celestial spheres with their planets and constellations ${ }^{28}$. And at this point of our analyze we can say that the starry sky is a symbol of eternity for all religions, be it Islamic, be it Jewish.

To give a last hint to Semper's inspirations coming from the Alhambra, I mention the freeze delimitating the dome of the synagogue, as it appears in his drawing. The freeze is ornate with an arabesque, for which we find models in the Alhambra publication, too. In conclusion, I can state that we are on the way to an exhaustive analysis of Semper's Dresden Synagogue and we find an intriguing apparition of decorations stemming from the Alhambra, mixed with other elements of Oriental-style ornaments, quite often interpreted in a new way by the architect.

\section{Bibliography}

\section{Arbeitsgemeinschaft 2016}

Arbeitsgemeinschaft für die Erforschung der Geschichte der Juden im süddeutschen und angrenzenden Raum, Speyer (Rhein inland-Pfalz), Jüdische Geschichte vom 17. Jahrhundert bis 1940 / Synagogengeschichte, <http://www.alemannia-judaica.de/speyer_synagoge.htm>. (accessed July 21, 2016).

DARBY I974

Michael Darby, Owen Jones and the Eastern Ideal. PhD diss., The University of Reading, 1974.

FLORES I 996

Carol Ann Hrvol Flores, Owen Jones: Architect. PhD diss., Georgia Institute of Technology, 1996.

Girault de Prangey i 837

Joseph-Philibert Girault de Prangey, Monuments arabes et moresques de Cordoue, Séville et Grenade dessinés et mesurés en 1832 et 1833. Paris: Veith et Hauser, 1837.

Girault de Prangey i 842

Joseph-Philibert Girault de Prangey, Choix d'ornements moresques de l'Alhambra. Monuments arabes et moresques de Cordoue, Séville et Grenade. Paris: A. Hauser, 1842.

GOURY/JONES I $836-1840$

Jules Goury and Owen Jones, Plans, elevations and sections of the Alhambra with the elaborate details of this beautiful specimen of Moorish architecture / from drawings taken on the spot in the year 1834 by Jules Goury and Owen Jones. London: Jones; Ackermann, 1836-1840.

GOURY/JONES I $842-1845$

Jules Goury and Owen Jones, Plans, elevations, sections and details of the Alhambra from drawings taken on the spot in 1834 by Jules Goury and in 1834 and 1837 by Owen Jones. With a complete translation of the Arabic inscriptions, and an historical notice of the kings of Granada, from the

27 See Karl Friedrich Schinkel, Die Zauberflöte, I. Act, 6 Scene: Sternenhimmel, Thron der Königin der Nacht, 1819-1824, Aquatinta and Etching colourized, Österreichisches Theatermuseum, Vienna. See Grabar 2013, 207. 
conquest of that city by the Arabs to the expulsion of the Moors by Pasqual de Gayangos. London: O. Jones, $1842-1845$.

Grabar 20I3

Oleg Grabar, L'ornement: Formes et fonctions dans l'art islamique, translated by Jean-François Allain, $2^{\text {nd }}$ ed. Paris: Flammarion, 2013.

HOPFENMÜLLER 2015

Annelie Hopfenmüller, Der Baukunstausschuss König Ludwigs I.. Exhibition catalogue (Bayrisches Hauptstaatsarchiv, München, July 21 - September 8 2015). München: Staatliche Archive Bayerns, 2015.

JONES I 836

Owen Jones, "No. 1. La Alhambra", The Literary Gazette; and Journal of Belles Lettres, Arts, Sciences \& c., 1004 (April 16, 1836), 253.

KüNZL I984

Hannelore Künzl, Islamische Stilelemente im Synagogenbau des 19. und frühen 20. Jahrhunderts. Frankfurt a. M.: Peter Lang, 1984.

MCSWEENEY 2015

Anna McSweeney, "Versions and Visions of the Alhambra in the Nineteenth-Century Ottoman World", A Journal of Decorative Arts, Design, History, and Material Culture, 22.1 (2015), 44-69.

Nerdinger/OechSLIN 2003

Winfried Nerdinger, Werner Oechslin, Gottfried Semper (1803-1879): Architektur und Wissenschaft. Exhibition catalogue (Architekturmuseum der Technischen Universität München, München, June 4 - August 31 2003, Museum für Gestaltung, Zürich, November 1 2003- January 25 2004). München et al:: Prestel Verlag, Zürich: gta Verlag, 2003.

Von Orelli-Messerli 20 io

Barbara von Orelli-Messerli, Gottfried Semper (1803-1879): Die Entwürfe zur dekorativen Kunst. Petersberg: Michael Imhof Verlag, 2010.

SEMPER I 834

Gottfried Semper, Vorläufige Bemerkungen über bemalte Architectur und Plastik bei den Alten. Altona: Johann Friedrich Hammerich, 1834.

SEMPER I 847

Gottfried Semper, "Die Synagoge zu Dresden: Von Semper, Professor der Baukunst zu Dresden”, Allgemeine Bauzeitung mit Abbildungen, 12, 1847, 127, Plates 103-107.

SEMPER I 85 I

Gottfried Semper, Die vier Elemente der Baukunst. Braunschweig: Verlag Friedrich Vieweg und Sohn, 1851. 